\title{
Morte e ressurreição do capitalismo: a propósito de Schumpeter
}

JEAN-JACQUES SALOMON

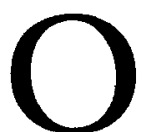
afinco com que Marx e Schumpeter, por razóes muito diferentes, anunciaram o desaparecimento do capitalismo em benefício do socialismo é um perfeito exemplo de como a análise científica pode se tranformar em ato de fé. No caso de Marx é absurdo, afinal de contas, espantar-se; e Schumpeter náo se absteve de salientá-lo: dentre todos os papéis que Marx desempenhou - historiador, sociólogo, economista ou filósofo - foi seguramente o de profeta que mais atraiu fiéis. Sua mensagem, diz Schumpeter, é a de uma religião que promete o Paraíso na Terra: "A seus fiéis, oferece, em primeiro lugar, um sistema de fins últimos que dão um sentido à vida e que constituem padróes absolutos de referência para avaliar os acontecimentos e as açóes; ademais, em segundo lugar, para alcançar tais fins, o marxismo oferece um guia que implica um plano de salvaçáo e a revelação do mal do qual deve ser libertada a humanidade ou um segmento eleito da humanidade" (1).

Ora, após ter consagrado a primeira parte de Capitalismo, socialismo e democracia a denunciar as contradiçóes e as ilusóes do marxismo, Schumpeter também conclui seu último livro com um exercício de profetismo igualmente temerário. A grande diferença em relaçáo a Marx é que sua mensagem não é a de uma religiáo - mesmo se, durante muito tempo, seus admiradores tenham dito que pertenciam, entre os economistas, a uma seita. Foi necessária a conjunção, nos anos 70 , da crise econômica e da emergência das novas tecnologias (informática, engenharia biológica, novos materiais de síntese, etc.) para que sua obra reencontrasse uma nova popularidade. Mas nunca deixou de ser um economista não-ortodoxo. Em 1942, publica Capitalismo, socialismo e democracia, ou seja, em um momento em que a religiáo marxista parece solidamente implantada na Rússia e em que os Estados Unidos Schumpeter tornara-se cidadão americano - estão longe de oferecer um modelo de capitalismo em decomposição. Em 1950, na véspera de sua morte, ainda corrige as provas de uma conferência que havia feito no congresso da American Economic Association, cujo título e conteúdo, " A 
marcha para o socialismo", mostram que ele persistiu, até o último momento, em sua prediçáo. Náo presenciou o desmoronamento da Igreja e do culto marxista a que nós assistimos. E, certamente, o socialismo que ele apregoava não era, de forma alguma, aquele que se configurou no comunismo. Três quartos de século após a revoluçáo de outubro de 1917, podemos nos interpelar se a pergunta que ele fez continua pertinente: estará o capitalismo destinado a transformar-se em socialismo?

Para Marx, embora sem data definida, o fim do capitalismo estava próximo, visto que esperava a ajuda da história, ou seja, a revoluçăo; em todo o caso, era preciso olhar para além do século. A partir de outubro de 1917, o horizonte dos prazos continuou diminuindo. Tanto para Lênin como para Trotsky, quando mal terminasse a metade do século, o capitalismo já estaria para sempre enterrado. Stálin, Krutchev e Brejnev apostavam menos ainda em seu futuro, afirmando seriamente que $o$ comunismo o "ultrapassaria" antes de uma década. Em compensaçáo, para Schumpeter, táo certo quanto Marx do fim do capitalismo, o prazo estava muito distante, tanto mais indeterminado que o golpe fatal devia vir não do exterior, mas do próprio seio do sistema. Aliás, concluía sua análise da "decomposição" dos valores burgueses, inerentes às virtudes dinâmicas do capitalismo, constatando que eles resistiam e que, nesse campo de previsão, um século representava um período a curto prazo (2). O profetismo de Marx invocava o "socialismo científico" que nada mais é que o desagradável sonho de uma utopia desmoronada: quanto mais ele se pretendeu científico, tanto mais os fatos desmentiram sua prediçáo. O profetismo de Schumpeter, que poderia ser tomado como sociológico, tem a vantagem de ser avaliado em um prazo muito longo, ou seja, em um espaço de tempo em que nenhum contemporâneo nem provavelmente várias geraçōes de nossos descendentes poderão comprovar. E também acarretaria menos consequiências, pois seu autor não oferecia nem promessa de salvaçáo, nem novo deus a ser adorado, nem estrutura que obrigasse os militantes à obediência do dogma. Em suma, oferecia apenas o discurso de um professor.

Quando nos interrogamos sobre as razóes pelas quais a história desmentiu a prediçăo de Schumpeter, interrogamo-nos, em suma, sobre o que faz do capitalismo industrial uma máquina que funciona com tanta eficácia. No sentido da termodinâmica, máquina nenhuma tem um rendimento de cem por cento, e a máquina capitalista náo escaparia dessa lei. Seus defeitos, seus limites, os desperdícios, os custos humanos do processo de destruifăo-criaf̧âa, o custo político das crises cíclicas são evidentes, mas sabemos doravante, por experiência, e năo mais apenas apenas pela teoria, que nenhuma outra máquina econômica pode riva- 
lizar em eficácia com o capitalismo - não fosse apenas por isso. Mas, se a termodinâmica acredita que qualquer máquina, com o tempo, tenha eficácia menor, o destino apontado por Schumpeter para o capitalismo é paradoxal: o esgotamento, e finalmente a morte, năo pelo desgaste ou pela entropia, mas pelo excesso de êxito, pelo exagero de rendimento.

Pelo menos, em dois pontos fundamentais, de caráter econômico e político, os fatos contestam as conclusóes de Schumpeter: o primeiro diz respeito ao futuro do processo da inovação; o segundo, ao papel do Estado nesse processo. Schumpeter apóia seu veredito em um terceiro ponto, de caráter psicossociológico e até filosófico que, a seus olhos, constitui o mais importante argumento: $o$ aumento do número e do estatuto dos intelectuais no sistema industrial e a hostilidade que tal sistema atrai para si por parte deles. Este último argumento é aquele que Schumpeter viu com mais justeza, mas não acredito que se preste às conseqüências por ele preditas.

\section{O conhecimento não suprime o acaso}

Por ter sido muito estudado e por causa da crescente mecanização do progresso industrial, o processo da inovação está destinado a um futuro fatal. "Com o correr do tempo, ele se reduz a pó, o que ocasiona, ao mesmo tempo, o desmoronamento do mais importante pilar que sustentava a posiçăo econômica da classe capitalista" (3). Uma economia centralmente planificada, que trata a inovação técnica como um bem público, năo pode melhor gerar nem melhor explorar as novas tecnologias, tanto quanto uma economia capitalista: a teoria permitiria afirmar isso; doravante, a história proíbe duvidar disso. Como salientou Richard Nelson, existem boas razóes para essa derrota que, por isso mesmo, explicam a capacidade que o capitalismo tem para se renovar $e$, portanto, para zombar do declínio que Schumpeter lhe atribuiu. A natureza da inovação é tal que mesmo a rotina científica não pode suprimir seu caráter aleatório. Efetivamente, nunca há receita ou precedente para orientar as escolhas com absoluta certeza. Todos os estudos feitos para identificar o melhor caminho a ser seguido se revelaram, mais tarde, falhos neste ou naquele aspecto, nesta ou naquela etapa (4). A inovaçáo é, por definição, um processo aleatório, jamais realizado de antemão, adotando, uma trajetória que nada tem de linear, tanto menos que a lógica das funçóes de uma invenção não coincide necessariamente com a lógica de seus usos: o inventor pensa que aperfeiçoou um produto ou um novo processo para este ou aquele uso, quando, na verdade, as aplicaçóes no mercado podem ser muito diferentes.

Inventar se tornaria um assunto de rotina se aqueles que decidem 
sobre a alocação dos recursos destinados às atividades de pesquisa pudessem abarcar todo o meio do qual a invençáo se nutre, responsabilizar-se por todas as informaçóes de que ela depende e, finalmente, substituir-se, em pleno conhecimento de causa, aos inventores que assumem o seu risco até conhecer o fracasso. Numa situação, onde é preciso contar com a sorte, o lugar da desordem é também o quinháo do diabo. Mesmo o inventor bem-sucedido terá, no final, alguma dificuldade em se vangloriar de ter, conscientemente, dominado todos os fatores decisivos do sucesso de sua invençăo. Por mais que as invençóes de hoje dependam mais estreitamente da ciência que as de ontem, é preciso ceder à evidência: como o lance de dados de Mallarmé, jamais a ciência abolirá 0 acaso.

Além disso, é preciso lembrar-se que a maior parte dos trabalhos consagrados à inovação técnica estuda os casos de êxito, e não as invençóes que não deram certo. Por exemplo, a grande maioria das invençóes que conseguiram patente do Patent Office americano nunca foi comercializada. O technology-push (pressão da oferta de tecnologia) e o market-pull (demanda do mercado) remetem a dois determinantes complementares, mas o segundo, freqüentemente, é mais fator de sucesso que o primeiro (5). A lógica da descoberta e da invençáo deve sempre ir ao encontro da lógica do mercado, a não ser que dependa das solicitações públicas e de colocar-se ao abrigo de mercados fechados. Mas, precisamente, quanto mais os mercados sáo protegidos, tanto mais a burocracia tem chances de reforçar os freios contra a tomada de risco. A concentraçáo do esforço de pesquisa-desenvolvimento em certos setores náo é uma segurança total para vencer as batalhas que virão da invenção, tanto menos que a pesquisa nada mais é que um fator entre outros, às vezes o menos determinante, no sucesso de um produto ou de um processo novo no mercado.

Por todas essas razóes, náo apenas a economia capitalista se presta melhor à invençáo que uma economia planificada, como, também, a economia planificada constitui, por sua própria natureza, um obstáculo à inovação. É que ela tende a reduzir o número de fontes de iniciativa e a rejeitar a concorrência entre aqueles que propóem diferentes caminhos para alcançar mais rapidamente $o$ objetivo almejado. $O$ acesso ao armazenamento dos conhecimentos fundamentais é mais fácil em um sistema não planificado, descentralizado e concorrência: as estruturas de produção não estão separadas das instituiçóes de formação nem dos laboratórios. Por definição, os incentivos têm maior peso para tornar o empresário atento aos sinais do mercado (verdade é que năo há sinais de mercado em uma economia centralizada), e onde se torna evidente que somos perdedores, não insistimos em preencher o déficit com a ajuda do 
Estado. Isso, certamente, não é entusiasmador e Schumpeter estava perfeitamente consciente disso, isto é, que o capitalismo seja perfeitamente eficaz ou despojado de desperdício. Ele náo o é, e nem poderia sê-lo, apesar dos progressos da ciência econômica das técnicas de administração: uma alocaçáo eficaz dos recursos é incompatível com a constelaçáo de iniciativas a montante e de monopólios temporários a jusante, que resultam da concorrência fundada na invenção.

Isso, pórem, não tem, afinal de contas, importância alguma aos olhos de Schumpeter que, muito explicitamente, acentua, no estilo germano-romântico que lhe é próprio, que a eficácia, enquanto tal, não é a condiçăo para o crescimento econômico: " A açăo dessa modalidade de concorrência (a invenção) ultrapassa a da concorrência dos preços, assim como os efeitos de um bombardeio ultrapassam os de uma pressão sobre uma porta, e sua eficácia é de tal forma maior que a questáo de saber se a concorrência, no sentido comum do termo, se desempenha mais ou menos rapidamente, torna-se relativamente insignificante: de qualquer modo, a poderosa alavanca que, com o tempo, eleva a produção achatando os preços, é de um calibre totalmente diferente" (6). Canhão contra pistola: a concorrência através da invenção não se opóe apenas à produçáo $e$ às margens lucrativas das firmas; ela atribui a culpa "aos fundamentos e à própria existência das firmas" . O dinamismo da economia está à mercê do rolo compressor da invenção; ao contrário, é às custas da estagnaçáo que a eficácia e a ausência de desperdício devem prevalecer.

Podemos, entáo, julgar contraditório que alguém que destaque tão fortemente o caráter revolucionário do sistema capitalista conclua que um termo seja ou deva ser destinado às faculdades intrínsecas de renovaçáo deșse sistema. Nada, no mundo social, diz ele, pode ser mais durável que o bronze $\mathrm{e}$, por conseguinte, a resposta à pergunta - "Pode o capitalismo sobreviver?" - , a seu ver, não apresenta nenhuma dúvida. Mas Schumpeter não é tão ingênuo como o faria pensar uma leitura sumária de seu pessimismo. Por várias vezes, insiste na idéia de que não existe nenhuma razáo puramente econdmica impedindo o capitalismo de transpor, com sucesso, novas etapas. E, de fato, o capitalismo contemporâneo já está muito diferente daquele por ele analisado. As invenções dos anos 40, "escondidas no seio dos deuses", deram seus frutos e, a seguir, outras năo deixaram de ser semeadas, renovando constantemente uma seara da qual ele não podia ter idéia.

Quando Schumpeter escreve que a invençăo, em vias de se transformar e uma rotina, leva o progresso econômico "a se despersonalizar e a se automatizar", é para anunciar o fim do empresário no sentido em 
que este se define pela vontade, pela firmeza, pelo espírito de risco. Seu papel é semelhante ao do comandante, até há pouco tempo presente no combate "sobre um fogoso cavalo". Schumpeter considera que o empresário é substituído pelo trabalho dos escritórios e das comissóes " como o trabalho de Estado-Maior está em vias de apagar a personalidade do chefe" (7). Ele está correto ao salientar que a descoberta científica e a invenção técnica não são mais um assunto "eminentemente individualista", mas se engana ao concluir que o trabalho de equipe compromete a capacidade de invenção, ou mesmo que o indivíduo nele desempenha um papel definitivamente menor. A evolução científica não destrói a funçáo do inventor "como a evolução técnica e social destruiu a cavalaria". Com efeito, nada diz que o trabalho de equipe, a industrialização da pesquisa, a rotina científica tornem menos importante a funçáo do empresário; e, da mesma forma, que o trabalho de Estado-Maior, "especializado e racionalizado", torne menos decisiva a função do general.

Foi precisamente o tema da racionalizaçáo científica e da crescente especialização da tecnoestrutura que Galbraith retomou em $O$ nopo Estado industrial ${ }^{* *}$ para salientar, ao contrário, a crescente eficácia do capitalismo. $O$ anonimato empresarial não suprime a cavalaria dos indivíduos inventores, assim como a concentraçáo do esforço de pesquisadesenvolvimento nas grandes empresas não suprime a capacidade para a invenção das pequenas e médias empresas. Vide o desenvolvimento das science based industries, na Rodovia 128, no Silicon Valey ou no Tridngulo Texano, assim como nos parques científicos e nas novas tecnópolis da maioria dos países industrializados da Europa e da Ásia; é claro que, longe de conduzir a uma letargia das virtudes inovadoras do capitalismo, a rotina científica as estimula e as reforça, renovando-as. O que, melhor dizendo, compromete hoje em dia a renovaçáo náo se deve às características cada vez mais científicas do sistema industrial, mas sim à cultura de gestão de certas empresas que, com os olhos fixos na rentabilidade a curto prazo e nas possibilidades de especulação, dão prioridade a suas funçôes financeiras em detrimento dos projetos de investimento a longo prazo de seus diretores de pesquisa.

\section{Socialização não é socialismo}

O segundo ponto em que Schumpeter visivelmente se enganou diz respeito à intervençăo do Estado nas atividades de pesquisa e de invençáo. O que ele entende por socializaçáo é o crescente responsabilizar-se do Estado por funçóes que pertencem à iniciativa privada e cuja administraçáo acarreta, a partir daí, sempre mais centralização, controle e burocracia. Quanto mais o Estado tende a planificar, a coordenar e a 
orientar a pesquisa-desenvolvimento, mais a inovaçáo fica ameaçada de enfraquecer e o empresário, de ser substituído pelo funcionário. Em 1942, quando publica Capitalismo, socialismo e democracia, Schumpeter vê na Uniẩo Soviética o modelo dessa socialização levado ao extremo e não se engana ao salientar que a capacidade de inovaçáo se ache aí consideravelmente reduzida, porque todas as instituiçóes de pesquisa estão éstreitamente dependentes da planificação e separadas do setor produtivo. Em compensação, nos Estados Unidos, antes da Segunda Guerra Mundial, o Estado Federal intervinha muito pouco nas atividades de pesquisa. Ainda em 1940, o apoio federal para pesquisa-desenvolvimento náo atingia a casa do bilhão de dólares, quantia pela qual o orçamento da defesa era muito inferior aos orçamentos da agricultura e da saúde juntos, entấo prioritários.

O dogma liberal postula, como lembra o próprio Schumpeter, a separação de direito e de fato entre o setor privado e o setor público. $O$ envolvimento americano na Segunda Guerra Mundial, e em seguida na guerra fria com a competição bipolar que a segue, vai atacar profundamente esse dogma. A mudança de proporção do esforço federal de pesquisa-desenvolyimento é particularmente ilustrada pelo programa $\mathrm{Ma}$ nhattan, fonte do armamento atômico, cujo custo se elevou a dois bilhóes de dólares em três anos, ou pelo programa Apollo, "o homem na lua", que representou, em dez anos, um investimento anual de cinco bilhōes de dólares. A ameaça soviética durante o governo Kennedy foi suficiente para obter-se do congresso, com o National Defense Act, o direito do poder federal de intervir na política de educaçáo e de pesquisa dos diversos estados. Hoje, o país que mais se vale da economia de mercado é também aquele onde o envolvimento federal ultrapassa mais da metade do esforço nacional de pesquisa-desenvolvimento, isto é, mais de setenta bilhốes de dólares por ano.

O conflito mundial inaugura, de fato, uma nova era na história das economias de mercado, onde vemos até os países menos dirigistas aceitarem a crescente intervençăo do Estado, tanto no setor universitário como no setor industrial, e isso em nome das funçóes que Schumpeter reservava exclusivamente à iniciativa privada. A ausência de paz, a bipolarização, a escalada dos armamentos em que desemboca o fim da Segunda Guerra Mundial, levam todos os países industrializados, encabeçados pelos Estados Unidos, a essa nova forma de capitalismo que Schumpeter não teria hesitado em denunciar como uma réplica do comunismo: está neles legitimado o apoio público para a pesquisa fundamental, mesmo nos países onde as universidades são privadas; o Estado se entraga a maciços investimentos nos programas de pesquisa-desenvolvimento em favor da defesa e do prestígio, embora náo estejamos em 


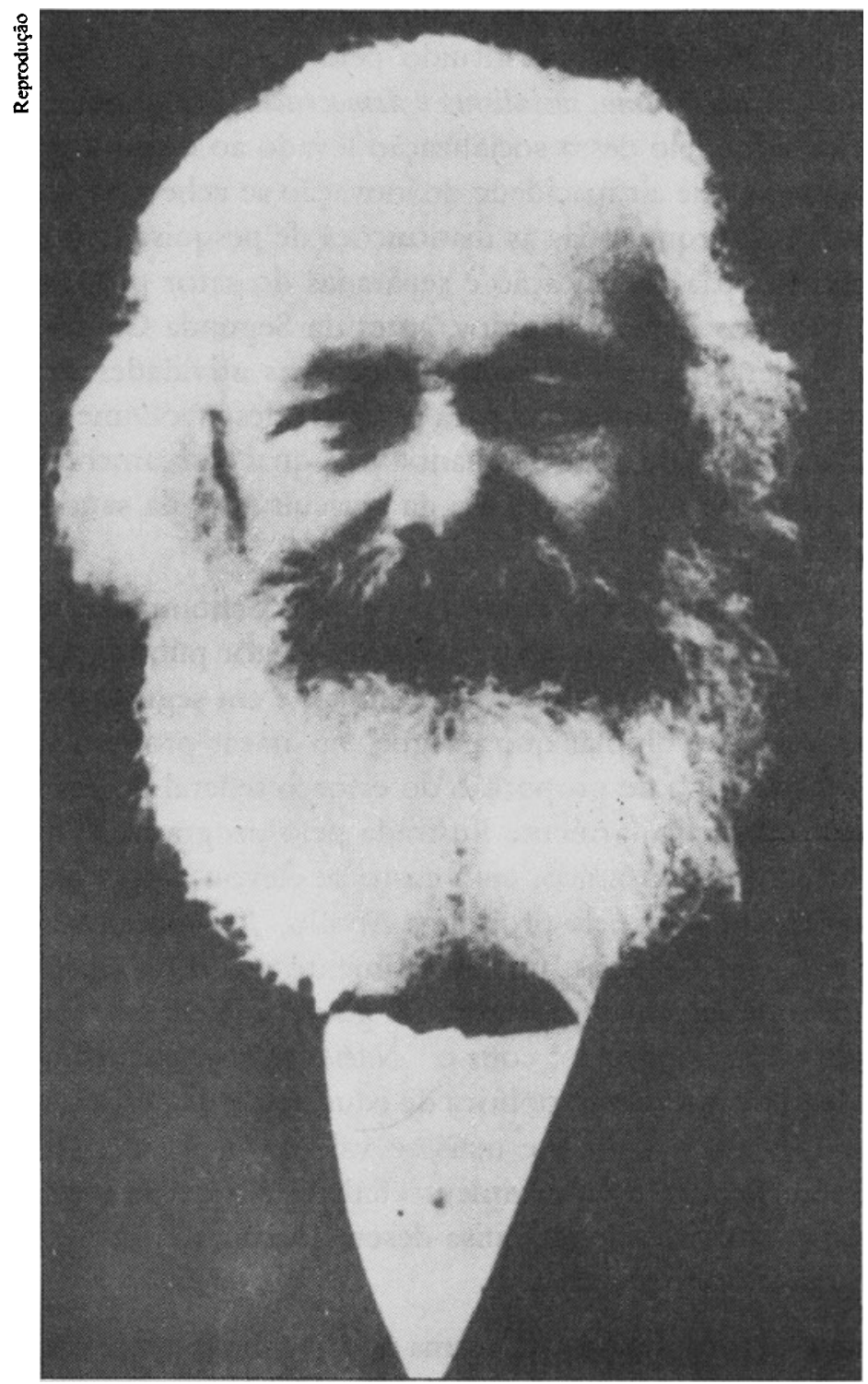

Karl Marx

1818-1883

estado de guerra (pelo menos declarada); as agências governamentais se lançam em programas de pesquisa aplicada cujos resultados contribuem para os lucros das empresas privadas; os fundos públicos se responsabilizam por uma importante parte do custo das pesquisas em que o setor privado se engaja, e contribuem diretamente para o financiamento das atividades de pesquisas feitas em cooperação pelas empresas em um estágio pré-concorrencial, fórmula pudica para legitimar, em nome da promoção da inovação, a ajuda do Estado às relaçōes interfirmas, que contornam as leis antitruste.

Incontestável socialização, que daria razão a Schumpeter, se reti- 


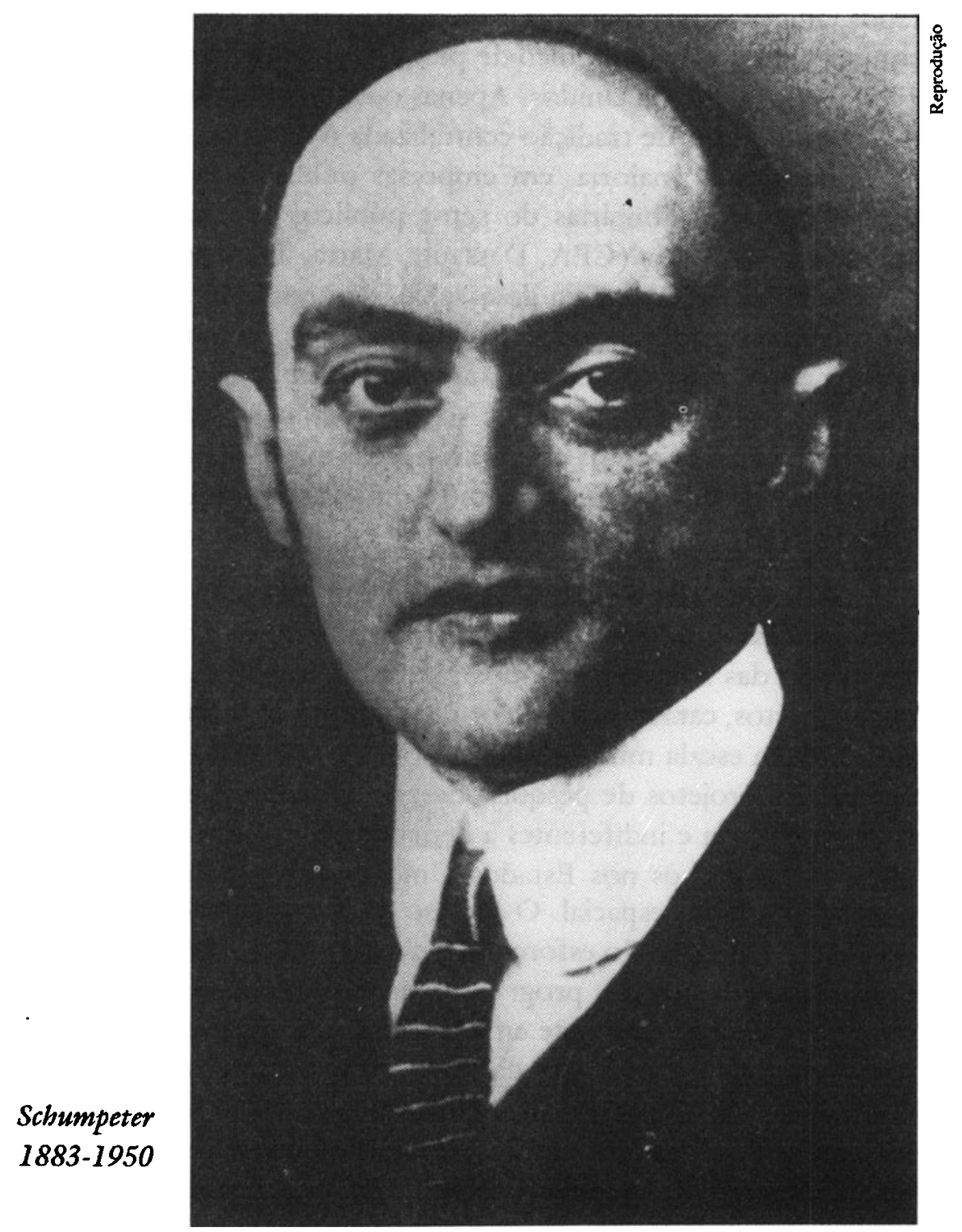

véssemos apenas essas conseqüências dos laços doravante estreitamente atados, em nome do imperativo da inovação, entre o setor privado e o setor público. Mas essa socializaçáo se confunde ainda menos com o comunismo, porque na maioria dos países de economia de mercado é o setor privado que executa a maior parte do esforço nacional de pesquisadesenvolvimento e porque boa parte desse esforço é mantida independentemente dos objetivos e dos financiamentos governamentais. Desse ponto de vista, seja qual for o papel mítico que alguns observadores ocidentais atribuam ao MITI, agência japonesa de tecnologia e de comércio internacional, não há nenhuma diferença entre o Japão e os Es- 
tados Unidos, ainda menos porque a parte do financiamento privado no conjunto do esforço nipônico de pesquisa-desenvolvimento é muito superior à dos Estados Unidos. Apenas o esforço de pesquisa-desenvolvimento dos países de tradição centralizada e dirigista, como a França, é feito, na grande maioria, em empresas públicas ou em empresas tão próximas e táo tributárias do setor público, que dele se diferenciam apenas em aparência (CEA, Dassault, Matra, Thomson, etc.). Todavia, o que chamei de estratégia do arsenal, que remonta a Colbert e se desenvolveu tanto durante a V República como durante o Segundo Império, nem por isso tornou a França de De Gaulle um modelo de regime socialista conforme os critérios schumpeterianos. Tanto menos que é nas empresas, e por essas empresas ligadas ao setor público, que a capacidade francesa de inovaçăo manifestou-se mais freqüentemente após a Liberação (8).

Ao contrário, a partir dos anos 70 , as grandes batalhas que decidem o sucesso das inovaçóes nas novas tecnologias acontecem não mais no campo das solicitações e dos mercados fechados, mas no dos mercados abertos, caracterizados por uma intensa concorrência entre firmas privadas em escala mundial. Exceto o setor da defesa, são precisamente os grandes projetos de pesquisa-desenvolvimento públicos, protegidos da concorrência $\mathrm{e}$ indiferentes à demanda do consumidor final, que conheceram fracassos nos Estados Unidos: centrais nucleares, avião supersônico, ônibus espacial. O sucesso da inovação năo aparece tăo freado pela socializaçáo do esforço de pesquisa-desenvolvimento como pela politizaçáo dos grandes programas, onde o interesse estratégico do Estado não esteja diretamente em causa. Mas, ao contrário do que antecipava Schumpeter, os atores da invenção não ficaram reduzidos aos escritórios e às comissóes dos órgãos públicos e não se reduziram às relaçóes entre as grandes empresas para limitar os riscos de suas atividades de pesquisa-desenvolvimento. Em sua estreita aliança com as empresas, o Estado liberal intervencionista nem mesmo desempenhou o papel do socialismo e, se ele náo deixou de ser liberal influenciando as atividades de pesquisa e de invenção do setor privado, foram os estados socialistas que se tornaram liberais ou aspiram a tornar-se, reorientando suas empresas públicas na direção do mercado (9).

\section{Incentivo e desvantagem dos armamentos}

De fato, o setor militar da pesquisa-desenvolvimento foi, por muito tempo, durante e após a Segunda Guerra Mundial, a fonte de inovações cujas aplicaçóes se estenderam ao setor civil (aeronáutica, energia nuclear, eletrônica, computadores, radares, satélites, antibióti- 
cos, DDT, etc.). Conduziu a uma forte concentração das empresas que mantinham atividades de pesquisa, estando, elas próprias, concentradas em um pequeno número de setores privilegiados. Também desse ponto de vista, Schumpeter falhou ao escrever que a açáo do Estado "pode ser considerada como um dado externo ao mundo dos negócios", particularmente no caso das despesas com armamentos que constituem "antes uma desvantagem do que um incentivo" (10). Durante cerca de um quarto de século, o esforço militar de pesquisa-desenvolvimento se traduziu, tanto nos Estados Unidos como na França, em realizaçōes em relação à inovação técnica $\mathrm{e} \mathrm{em}$ incontestáveis consequiências no setor civil. Na verdade, podemos discutír o custo disso, nos interrogar sobre os laços entre a racionalidade econômica e a racionalidade estratégica e, particularmente, considerar que a escalada dos armamentos desviou recursos raros, em capital e em competência, que poderiam ter sido destinados a atividades econômica e socialmente mais produtivas. Porém, é impossível subestimar a importância das inovaçōes que a pesquisa-desenvolvimento militar multiplicou durante esse período e o papel que representaram na administração e no desenvolvimento das novas tecnologias, que dão uma reviravolta na paisagem econômica, social e cultural deste fim de século.

Nesse período, que vai dos anos $\mathbf{4 0}$ ao começo dos anos $\mathbf{7 0}$, o esforço militar de pesquisa-desenvolvimento não constitui declaradamente uma desvantagem para a inovação. Mas, sem dúvida, constitui uma desvantagem do ponto de vista do crescimento econômico, em particular, quando comparamos a taxa de crescimento da produtividade dos países cujo esforço militar de pesquisa-desenvolvimento foi importante e a taxa onde ele pouco contou. Os países vencidos da Segunda Guerra Mundial, Alemanha e Japão, que se viram proibidos de iniciar importantes projetos no campo militar, conheceram, durante esse período, uma taxa de crescimento da produtividade e de desempenhos tecnológicos no mercado comercial muito superior à taxa dos Estados Unidos, do Reino Unido e da França. Estes últimos países são aqueles cujo esforço militar de pesquisa-desenvolvimento foi, no Ocidente, mais alto. Para cada um deles, o programa conjunto de defesa, de energia atômica e projetos espaciais atingiu e, em alguns anos, ultrapassou de longe a metade do conjunto de seu esforço de pesquisa-desenvolvimento.

A partir dos anos 70, a oferta de invençóes resultantes do setor militar se distancia cada vez mais das necessidades dos consumidores civis. As exigências das estratégias no que diz respeito às performances, tanto quanto aquelas dos sistemas técnicos em jogo como no caso do programa SDI, guerra nas estrelas (fiabilidade, miniaturizaçäo, resistência a condiçóes extremas, etc.), levam a produtos cada vez mais difíceis 
de se adaptarem aos mercados civis. E, simultaneamente, em certas áreas de alta tecnologia (em particular os semicondutores), os mercados civis suplantam as solicitaçóes militares como estimulantes da inovação. Essa inversão do cenário tecnológico em relação aos dias que se seguiram à Segunda Guerra Mundial deveria fortalecer a análise de Schumpeter sobre a desvantagem das despesas de armamento e, mais amplamente, fornecer um argumento de peso a seu processo do Estado intervencionista. Mas as coisas não são tão simples; mais precisamente, apesar do dogma liberal, não é nem fácil nem principalmente desejável retornar à aliança contraída entre o setor privado e o setor público. Aqui, ainda, é preciso recorrer a Galbraith para compreender as razóes pelas quais a escalada dos armamentos, característica da guerra fria, foi um estimulante da inovação. A competição das potências bipolares legitimou o desenvolvimento de um vasto setor público e a crescente intervençáo do Estado no setor civil, de onde o mundo dos negócios tirou partido. A escalada dos armamentos era uma mina de ouro, enquanto, precisamente, as duas potências bipolares dividiam o mesmo sentimento de insegurança. "Uma guerra sem combate", diz Galbraith, "evita habilmente o risco de ver o combate cessar. $O$ desuso está mais ou menos para a competição tecnológica como a usura está para a guerra" (11). $\mathrm{E}$, enquanto durasse a guerra fria, a suspensão da competição era vista como mais perigosa que a própria competição.

O período após a Segunda Guerra Mundial termina no nocaute econômico do sistema comunista, na dissoluçáo do Pacto de Varsóvia, na implosão do império soviético. A assinatura dos acordos START acarretava uma redução de trinta por cento dos armamentos estratégicos de longo alcance; a nova doutrina estratégica do presidente Bush promete cortes ainda mais drásticos no arsenal nuclear. Estaremos caminhando em direção à menor socialização das atividades de pesquisa e de inovação nos Estados Unidos? Essa hipótese me parece absolutamente excluída a médio prazo: a redução dos armamentos estratégicos não é ainda o desarmamento, $e$ a desescalada da corrida aos armamentos (sua diminuição $\mathrm{em}$ volume) nem por isso implica a desescalada dos programas militares de pesquisa-desenvolvimento - mesmo se, para alguns deles, houver menor urgência em lhes pôr termo. $O$ fim da guerra fria não me parece tornar mais plausível a versão schumpeteriana, onde a socialização do esforço da pesquisa deve rimar com o esgotamento da inovação. As posturas estratégicas vão mudar, porém, sem comprometer as capacidades de dissuasão e de réplica.

Por um lado, a redução dos armamentos năo se traduzirá por menor sofisticafão dos sistemas de armas: o abandono dos mísseis nu- 
cleares táticos e foguetes intercontinentais de ogivas múltiplas acarretará consideráveis esforços de pesquisa-desenvolvimento para fazer progredir a defesa antimíssil e para melhorar a qualidade dos armamentos convencionais. Por outro lado, se o desmoronamento do mundo comunista mina a base tradicional da legitimidade do complexo militar-industrial, as desordens que se podem seguir, na Europa Central e principalmente no que resta da União Soviética, não permitem aos ocidentais relaxar a vigilancia. A volta da Europa a uma situação mais próxima de 1848 do que de 1948 não será uma garantia mais sólida de verdadeira paz quanto náo o era o equilíbrio pelo terror. $\mathrm{E}$, se as ameaças que pesam sobre o mundo ocidental náo têm mais a Europa por epicentro, o desequilíbrio pelo terror, ligado a outros continentes, proíbe pensar que a era da paz perpétua está ao alcance da mão.

Enfim, perfila-se uma versáo que nada mais tem a ver com as conclusōes de Schumpeter ou mesmo com as de Galbraith. Doravante, a competiçáo não mais será bipolar, mas multipolar, orientada não mais para a potência militar, mas para a potência econômica, antes reforçando do que desacreditando o imperativo da inovação. Se, a partir de 1945, a defesa proporcionou a melhor caução à tecnologia, a guerra econômica, bem antes da queda do muro de Berlim, fez uma pausa e assegura-lhe uma cauçáo também sólida. Aquilo que François Perroux chamava de a "luta-concorrência" continua, cada vez mais, com protagonistas mais numerosos, lances estratégicos renovados, portanto também diferentes vencedores e vencidos. $O$ cenário inesperado é o de um poderio militar americano sem igual no mundo, mas cuja economia diminui de tanto perder seu leadership tecnológico, sem que por isso a dinâmica do capitalismo seja, de resto, afetada - ao contrário. Os americanos viram o diabo no socialismo, assim como os comunistas viram o diabo no capitalismo. Estes pagam muito caro sua recusa em reconhecer a capacidade de inovação de um sistema aberto à concorrência. Aqueles podem enfrentar dissabores não menos dramáticos, ainda que diferentes: náo se trata apenas da alocaçáo maciça de sua mão-de-obra científica e técnica no setor da defesa, como também, e principalmente, de sua incapacidade de reconhecer as virtudes, ainda que de um socialismo bemtemperado, quando este sabe servir-se do Estado e mobilizar funcionários competentes para implantar uma política industrial. Desse ponto de vista, a Alemanha Federal, bem mais que a França, constantemente deu o exemplo de um intervencionismo muito eficaz em matéria de pesquisa e invenção: tanto as pequenas e médias empresas quanto as grandes aproveitaram-se da generosidade do apoio governamental.

Para que servem os intelectuais 
Para Schumpeter, finalmente, a doença entorpecedora que deve levar o capitalismo à morte não concerne às estruturas, nem aos processos econômicos, mas à atmosfera de hostilidade que o cerca. Como diz ele, pouco importa que haja necessidade de semideuses para conduzir a locomotiva socialista e arcanjos para aquecê-la, é deste lado que a balança da história pende inexoravelmente. Não há nenhuma necessidade de se recorrer a uma explicação econômica como, por exemplo, à teoria do desaparecimento das oportunidades de investimento para perceber os distúrbios funcionais que fazem do capitalismo um morto em sursis. A questão é de ordem sociológica, cultural, ética, ideológica, tudo o que o leitor quiser de Montesquieu a Veblen, passando por Sombart e Weber.

A atmosfera geral de hostilidade que permeia o sistema capitalista explica que os poderes públicos hesitem, ou até deixam de reconhecer as exigências inerentes ao bom funcionamento do sistema mas, por si mesma, não seria suficiente para abater a fortaleza. Para incitar as massas, os partidos, os sindicatos, é preciso um demiurgo, cujo interesse é precisamente contribuir para o descrédito de todo o sistema, maldizê-lo e combatê-lo. Esse demiurgo, diz Schumpeter, é constituído de um grupo social onde raramente encontramos políticos profissionais $\mathrm{e}$, mais raramente ainda, pessoas que exerçam responsabilidades. É um grupo social "de difícil definiçáo, e essa dificuldade é até um dos sintomas associados à espécie". Podemos porém, grosso modo, reconhecer seus membros nas atitudes que adotam e nos interesses que desenvolvem evocando o comportamento de uma classe social, "mesmo que acorram de todas as partes da sociedade e que grande parte de suas atividades consista em se combaterem uns aos outros" (12). Ou ainda, facilmente nós os definiríamos em funçáo da educaçáo superior que receberam, ainda que a espécie não englobe todos aqueles que se beneficiaram dessa formação (mas todo aquele que passou por ela é um desses demiurgos em potencial). Nós os encontramos particularmente nas profissōes liberais: são jornalistas e professores, mas também médicos e advogados, "quando tratam através da fala e da escrita de assuntos estranhos à sua competência".

Esses demiurgos, incansáveis coveiros do capitalismo, são intelectuais que manejam, diz Schumpeter, a palavra escrita ou falada, não assumem nenhuma responsabilidade no que concerne às questôes práticas, não possuem nenhum dos conhecimentos de primeira mão que apenas a experiência fornece, têm uma atitude crítica determinada ao mesmo tempo por sua posiçáo de observadores (que é, na maioria dos casos, a de outsiders) e devido ao fato de que sua melhor oportunidade de se impor se deve aos embaraços que suscitam ou poderiam suscitar. 
Como vemos, retrato pouco amável: retóricos, sofistas, filósofos. Pensaríamos estar ouvindo aquele ministro da Defesa francês falando, na época da Guerra da Argélia, dos "caros professores" que a ela se opunham. Não vou procurar desculpar Schumpeter por mostrar-se tão severo em relaçáo aos intelectuais dos quais se diferenciaria, segundo sua definição, apenas pela parte que lhe coube desempenhar nos assuntos públicos, quando foi, enquanto membro do Partido Social-Cristão, ministro das Finanças da Áustria. Não nos esqueçamos de que, de sua experiência austríaca na Segunda Guerra Mundial, teve de lidar, tanto à direita como à esquerda, entre fascismo, nazismo e comunismo, com um excesso desses demiurgos que o ódio ao capitalismo tornou cegos ou complacentes com todos os crimes da metade do século. Não teria, aliás, proliferado, após a Segunda Guerra mundial, uma espécie também complacente e cega com os processos na Europa Central, as loucuras de Mao e os cambojianos vermelhos? Mas, sejamos justos: nem todos os intelectuais pertencem fatalmente ao clã desses demiurgos. De fato, mais significativos que a definição de Schumpeter para os intelectuais, é o lugar que ele lhes atribui, no sistema capitalista $e$ a ingenuidade com que considera que esse sistema os educa e os mantém: "Diferentemente de qualquer outro tipo de sociedade, o capitalismo, devido à própria lógica de sua civilizaçáo, tem, por resultado inevitável, educar e subvencionar os profissionais da agitaçáo social" (13).

Em suma, Schumpeter faz aqui capitalismo e democracia caminharem ao mesmo passo: a lógica do melhor bem-estar assegurada pelo dinamismo da economia se confunde com a liberdade de criticar que os regimes democráticos preservam. Gostaríamos que assim fosse, mas é evidente uma aventura unir táo estreitamente o destino da democracia ao destino do capitalismo. Nada diz que o casal tenha sido feito para prometer-se um ao outro nem para contrair núpcias duradouras. A história do século XIX, e, com mais fortes razóes, a do século XX mostra, ao contrário, que os casos de harmonia conjugal são exceçáo. Năo é o capitalismo que garante o bom funcionamento das estruturas democráticas, ao contrário, são as estruturas democráticas que garantem o bom funcionamento da economia de mercado. Schumpeter constata a coincidência do nascimento do Humanismo com o do capitalismo, onde, segundo ele, estaria o início, com Aretino, do desenvolvimento dos intelectuais, críticos e tributários do poder. Não sei se ele tem razão ao associar tão estreitamente essas duas certidóes de nascimento, mas a continuação de sua análise merece reflexáo. Carlos $\mathrm{V}$, subornando Aretino, que, por sua vez, lhe atribuía com panfletos insultos, anuncia, segundo Schumpeter, a era do capitalismo industrial que, fazendo causa comum com a democracia, precipita a expansão do aparelho educativo 
e, em particular, multiplica as facilidades dadas ao ensino superior, de onde resulta um número sempre maior de intelectuais, portanto, de procuradores do sistema. A pena de Aretino, constata Schumpeter, foi mais forte que a espada. Sem dizê-lo explicitamente, sugere que a crescente hostilidade que inundará o capitalismo coincidirá, por sua vez, com a obstinada crítica da qual o Humanismo será objeto: morte do homem, morte do capitalismo, mesma luta, em suma, de Marx e Nietzsche a Foucault. Em todo caso, é certo que, quanto mais o capitalismo se enraíza em estruturas democráticas, tanto mais os intelectuais têm lazer - em todos os sentidos do termo - para consertá-lo.

É nesse ponto que a análise de Schumpeter mostra-se premonitória. O próprio sucesso do capitalismo, que estimula e expande a educação superior, acaba por provocar uma "superprodução de intelectuais" sem indulgência para o sistema. Um número sempre maior de diplomados não encontra as ocupaçóes profissionais às quais seus estudos lhes permitiam aspirar, sem falar daqueles que, apesar de seus estudos, conhecem o desemprego. Quanto mais os diplomados de ensino superior se propagam, tanto mais se desvalorizam, e mais as frustraçóes se multiplicam e aumentam. Os recém-formados "incham os quadros dos intelectuais no sentido estrito do termo, ou seja, aqueles sem vínculos profissionais, cujo número em seguida cresce desmedidamente. Eles entram nesse exército com uma mentalidade essencialmente insatisfeita. A insatisfaçáo gera o ressentimento" (14). Para Marx, o exército de reserva de desempregados devia contribuir, reforçando o partido dos proletários, ao desabamento da fortaleza capitalista. Para Schumpeter, os burgueses e pequenos-burgueses que passaram pelo ensino superior constituem o exército de reserva dos novos proletários, que váo contribuir para a "autodestruição do capitalismo". Resumindo, esses intelectuais estão reunidos por "um interesse coletivo que modela uma atitude coletiva" : sua hostilidade em relaçáo ao capitalismo, diz Schumpeter, se fundamenta no ressentimento, e náo na indignaçáo provocada pelo espetáculo de exploraçôes vergonhosas. Após terem dado voz, teorias e slogans ao movimento operário, nossos demiurgos vão se imiscuir nas administraçóes e empresas para mobilizar as frustraçóes das novas classes médias. Esse trabalho de solapamento precipita o fim dos empresários e da inovação. "Como alvo da crescente hostilidade de seu ambiente e das práticas legislativas, administrativas e judiciais geradas por essa hostilidade, os empresários acabarāo por deixar de preencher suas funçóes: seus objetivos normais se tornarăo fúteis" (15).

É difícil contestar esse diagnóstico acerca das frustraçōes decorrentes das universidades de massa, da proliferaçáo dos formados, da 
desvalorização dos títulos, cuja obtenção valia, às geraçốes anteriores à Segunda Guerra Mundial, uma promoçáo social assegurada, um passaporte de burguesia, uma garantia de poder e de patrimônio. $O$ capítulo XIII do Capitalismo, socialismo e democracia é, seguramente, aquele que a história menos desmentiu, ou pelo menos aquele cujos temas encontram hoje mais eco na crítica das complacências ou da vulnerabilidade das sociedades liberais. No quadro dos fatores que devem cavar o túmulo do capitalismo, Schumpeter acrescenta à proletarização do ensino superior "o crescimento dos recursos; os progressos sobrevindos em matéria de nível de existência e de lazeres de massa, que modificaram e continuam a modificar os elementos que constituem o mecenas coletivo a cuja vontade os intelectuais devem se curvar; a redução (não concluída) do preço dos livros e dos jornais; as editoras de grande porte; e, doravante, o rádio; enfim, hoje como ontem, a tendência à completa abolição de qualquer coação, paralisando regularmente essas tentativas natimortas de resistência ao longo das quais a sociedade burguesa dá provas, em matéria de disciplina social, de tanta incompetência e, às vezes, de tanta infantilidade" (16). Ele não podia prever a expansáo da televisão e das novas mídias. Mas, se acrescentarmos a esse quadro os efeitos do walkman e dos clips, a anticultura, as ervas e a permissividade californiana, esse capítulo pareceria já ter sido escrito por Allan Bloom.

\section{Fênix que renasce das cinzas}

Schumpeter, entretanto, se engana a respeito do desemprego dos intelectuais. Todas as estatísticas mostram que, em todos os países industrializados, a categoria dos diplomados de ensino superior escapa mais facilmente do desemprego ou encontra mais facilmente trabalho do que todas as outras categorias. Ele tem razão ao salientar que nem todos esses diplomados exercerão necessariamente as profissóes às quais se destinavam quando começaram os estudos, mas se engana ao ver neles um exército homogêneo obstinado em querer a morte do capitalismo. Os frustrados, como sugere Brettecher, pretendem, antes, tirar partido do sistema que suprimi-lo. Seguramente, a sociedade de consumo, a elevação do nível de vida e a simultaneidade das experiências contraditórias apresentadas pelas mídias aumentam o número de frustraçōes, assim como o número de frustrados; porém, o número de pessoas cujo crescimento econômico e cujo progresso tecnológico satisfazem as necessidades, as aspiraçóes e as fantasias cresce ainda mais.

Enquanto não encontrar outra forma de expressão além do ressentimento, a contestação do sistema permanecerá marginal. A hostilidade votada ao capitalismo pode culminar em crises como a de 1968 
e em atos terroristas como as brigadas vermelhas nas quais, efetivamente, os intelectuais desempenham o papel de demiurgos (o papel principal), Mas, nem por isso, ela culmina no fim wagneriano do capitalismo nem no desaparecimento do empresário. Todos os fatores que, segundo Schumpeter, devem conduzir o capitalismo à ruína podem igualmente aparecer - uma vez superadas as crises e talvez por causa do próprio estimulante dessas crises - como o que faz a fênix renascer das cinzas, e a faz partir para um vôo mais alerta do que nunca: bastou, na França, reabastecer os postos de gasolina para, em maio de 1968, deter de pronto aquilo que passava por uma revoluçáo.

Longe de diminuir, diz Schumpeter, a hostilidade se acentua cada vez que a evoluçáo capitalista se traduz por um novo êxito: nada é táo evidente nem táo demonstrado se pensarmos nos sonhos que a volta ao capitalismo provoca nas antigas democracias populares, e nas reaçóes da grande maioria das populaçóes, nas democracias ocidentais, a essa quase biológica rejeição ao comunismo. A hostilidade nem assim desaparece, pois o desmoronamento do comunismo não suprime os defeitos e os excessos do capitalismo, porém, muda de forma assim como de meios, sem acarretar os grandes movimentos de massa, manipulados por intelectuais tanto de direita como de esquerda, nos quais Schumpeter pôde ver a irreprimível alavanca do fim do capitalismo. Há lugar, por certo, para novas contestaçóes, e a implosão comunista torna tanto mais verossímil a conjunçáo dos ressentimentos que a esperança sempre legítima de uma divisão menos desigual das riquezas e o excesso de triunfo do darwinismo da economia de mercado podem suscitar. Mas náo é isso que condenará a empresa a tornar-se fóssil; nem a inovaçáo, fútil, nem o capitalismo, obsoleto.

Enquanto isso, o crescimento das classes médias não tem, como consequiência, uma burocratização maior mas, pelo contrário, uma vontade e um poder melhor partilhados de controlar a burocracia. Ao menos nos países mais industrializados, a própria natureza e o objetivo das batalhas políticas são modificados com movimentos extraparlamentares que não procuram derrubar o sistema, mas acomodá-lo em função das causas locais às quais se consagram, como, por exemplo, o meio ambiente e a qualidade de vida. E o que ameaça a democracia năo é a anemia do capitalismo, mas o desinteresse pela verdadeira política, no sentido tradicional, e a distância que não cessa de se cavar entre o jogo dos profissionais da política e os problemas do cotidiano, reais ou imaginários, tais como săo vividos pelos indivíduos ou grupos.

A previsão econômica a longo prazo é um projeto de visionário, não um empreendimento científico. A previsão de Schumpeter se fun- 
damenta antes nos atores e nas instituiçóes do capitalismo do que nas atividades econômicas, ela năo corresponde aos fatos. $O$ moribundo está bem vivo e desconhece até mesmo uma nova juventude. Tudo se passa ao contrário, como se o capitalismo nảo cesasse de encontrar em si próprio as molas de sua renovação: dotando seu reservatório tecnológico de recursos inéditos; a base de suas instituiçōes, com fundaçōes transformadas e, principalmente, o palco de seu teatro, de atores vindos de continentes novos. Assim como a União Soviética não podia ser considerada como a vanguarda do socialismo, os Estados Unidos não podem mais passar pela vanguarda do capitalismo. $O$ futuro econômico do capitalismo americano não prefigura necessariamente o do capitalismo dos países cuja industrialização é mais recente. A perda de leadership tecnológico e o declínio previsível da economia americana năo significa nem o fim do empresário ou da inovação, nem o triunfo do socialismo planificador ou da burocracia centralizada. De fato, vemos desenvolver-se um capitalismo cujas expansóes tecnológicas invocam, ao invés de recusar, a arbitragem do Estado. $O$ questionamento do Estado-providência não acarreta o questionamento do Estado que controla os excessos da mudança téçnica. $\mathrm{E}$ as regulamentaçōes impostas ao "perpétuo furacăo de destruição criadora" têm, por conseqüência, não asfixiar a invençáo mas, ao contrário, inseri-la em uma rede de estimulantes que a obriguem a renovar-se em função das mudanças de valores cujo teatro é a sociedade. É o caso, por exemplo, das regulamentaçóes relativas à poluição provocada pelos automóveis; e, com mais forte razáo, o das preocupaçóes que suscitam, em escala mundial, as ameaças à biosfera devidas à industrializaçáo. A questão do meio ambiente, que se tornou um assunto político discutido no seio das Naçóes Unidas, mostra bem que, doravante, o laissez-faire tecnológico, em qualquer lugar que esteja, não é inevitável tal como o laissez-faire econômico.

Em teoria, é possível, de fato, que a sociedade de amanhá, saturada de progresso tecnológico e convertida a um ecologismo primário, escolha recusar, $e$ até proibir, as invençóes que a arrastem a um turbilhão incontrolável de transformaçóes técnicas e institucionais e, portanto, caçar os empresários, culpados de sentir prazer em perturbar o estoque de produtos e de processos disponíveis e submeter o sistema econômico ao choque sempre renovado da mudança. Mas este cenário me parece pouco verossímil, e não estou certo, aliás, de que o sistema econômico que dele resultasse se assemelharia, no que quer que seja, ao socialismo que Schumpeter imaginava. De fato, o processo de inovação não cairia vítima da rotina científica e da socialização do risco mas, por uma espécie de lassidáo, de uma recusa coletiva às ameaças que o caráter intrinsecamente revolucionário do capitalismo industrial faz pesar. Che- 
garíamos, assim, a uma sociedade tomada de uma anorexia tecnológica, cujo desejo de inovaçáo diminuiria até desaparecer. $O$ que não seria tampouco a versáo do Estado estacionário, segundo Schumpeter, onde lucros e taxas de juro convergeriam para zero. "Os empresários se veriam privados de qualquer campo de atividade e se encontrariam em uma situação análoga à dos generais em uma sociedade onde a paz perpétua estaria perfeitamente garantida." Supondo que este cenário seja concebível, não é uma economia estável que veríamos nascer, mas uma economia suicida que veríamos morrer.

No campo social, evidentemente, nada é mais durável que o bron$\mathrm{ze}, \mathrm{e}$ as civilizaçóes se sabem mortais. Mas a analogia com o ser vivo não é suficiente para explicar a tendência dos economistas evolucionistas de predizer o radical desaparecimento do sistema capitalista, cuja capacidade de renovação, no entanto, eles exaltam. Se nada há, como diria Schumpeter, que postule de um ponto de vista econômico o desaparecimento do capitalismo, as razóes de ordem psicológica e sociológica que ele propôs parecem tão frágeis e passionais quanto argumentos ideológicos. Trata-se, resumindo, de fazer da história um romance naturalista de onde $o$ acaso, a necessidade e principalmente a vontade são banidos em proveito de uma lógica que se assemelha, uma vez mais, ao destino. Luta de classes assegurando o triunfo do proletariado ou rotina científica anestesiando a inovação, o caminho cavado pela história não é, decididamente, o caminho que Marx e Schumpeter anteciparam. Não estamos, é verdade, no fim desse caminho, mas a longo prazo, como diria Keynes, não estaremos mais aqui para presenciar o que acontecerá com ele. Para os profetas que mostram a respeito do capitalismo a própria hostilidade que Schumpeter atribuía a todo intelectual, o fim do caminho nada mais pode ser que declínio, caos e morte. Assim sendo, é possível que vejam em suas próprias frustraçōes a mola mestra da história universal. É, porém, mais caridoso concluir que todo profeta tem seus limites.

Notas

1 Joseph Schumpeter, Capitalisme, socialisme, dtmocratie, Petite bibliothèque Payot, Paris, 1969 , p. 21.

2 Ibid., p.227.

3 Ibid., p. 12.

4 Richard Nelson, "Capitalism as an engine of progress", Research policy, North-Holland, 19, 1990, pp. 139-214, e The proceedings of the NISTEP Intenational Conference on Science and Technology Policy Research, Mita Press, Tokyo, 1991, pp. 61-87.

5 Vide Nathan Rosenberg, " The impact of technological innovation: a historical view", 
em Ralph Landau e Nathan Rosenberg (ed.). The positipe Sum Strategy, National Academy Press, Washington, 1986.

6 Joseph Schumpeter, Capitalisme, socialisme, democratie, p. 124.

7 Ibid., p. 187-188.

8 Jean-Jacques Salomon, Le gavibis, le cow-boy at le samourat: la politique frangenise de la technique, Economica, Paris, 1986, e "La capacité d'innovation", cap. I, Entre l Etat tt le marcht: bistoire tconomique de la France comtemporaine, Maurice Lévy-Leboyer e JeanClaude Casanova (ed.), Gallimard, Paris, 1991.

9 Vide Bertrand Bellon, L interpontionnisme libtral, Economica, Paris, 1986, e Alain Bucaille e Berold Costa de Beauregard, Les Etats, acteuts de la concurrence industrielle, Economica, Paris, 1988.

10 Joseph Schumpeter, Capitalisme, socialisme, dimocratic, p. 154.

11 John Kenneth Galbraith, Le noupel Etat industriel, Gallimard, Paris, 1967, p. 334.

12 Joseph Schumpeter, Capitalisme, socialisme, dimocratie, pp. 204-205.

13 Ibid., p.204

14 Ibid., p.217.

15 Ibid., p.211.

16 Ibid., p.185.

\section{Resumo}

A crise económica e a emergência das " novas tecnologias" nos anos 70 trouxeram nova popularidade à obra de Joseph Schumpeter. Neste artigo, o autor discute como a História recente tem desmentido as previsőes do economista quanto à transfotmação do capitalismo em socialismo.

Em primeiro lugar, năo ficou provado que a racionalizaçăo do progresso industrial reduz o nível de inovaçăo, extinguindo os papéis do empresário e do inventor. Pelo contrário, o caráter aleatório da inovaçấo é tal que uma economia não-planificada se adqua muito methor à sua natureza.

Quanto ao segundo aspecto, a presença crescente do Estado nas atividades de pesquisadesenvolvimento, o cenário mundial de 1945 alterou-se drasticamente a partir da década de 70 quando a demanda dos mercados civis por alta tecnologia passou a superar as demandas governamentais.

O terceiro ponto diz respeito ao papel dos intelectuais, pois a expansáo e simultânea desvalorizaçăo do ensino superior geram uma superpopulaçăo de indivíduos que desenvolvem uma visão crítica com relação ao sistema. Mas se tal "hostilidade" nutre-se apenas de ressentimento, como Schumpeter acredita, jamais terá força para por um fim no capitralismo. Assim, se nāo há nada que, de um ponto de vista económico, postule o desaparecimento do capitalimo as razóes sociológicas e psicológicas apresentadas por Schumpeter têm a mesma debilidade de argumentos ideológicos.

\section{Abstract}

The economical crisis and the emergence of the "new technologies" in the 70's brought a new popularity to the work of Joseph Schumperer. In this article, the author discusses how recent history has danied Schumpeter's predictions concerning the passage of capitalism to socialism.

First of all, it has not been proved that rationalization of industrial progress reducts the level 
of inovation, extinguishing the roles of the entreprensur and the inventor. It is quite the opposite, for the aleatory character of inovation is such that a not-planned economy suits much better its nature.

Concerning the second aspect, the growing role of the State in the activities of researchdevelopment, the world scene of 1945 has changed drastically from the 70's onward when the civil markets demand for high technology outweighted the public demands.

The third point relates to the function of intellectuals. The expansion and simultaneous devaluation of superior education generate an exceeding number of individual who develop a critical view towards the system. But if such "hostility" is due only to resentment, as Schumpeter believes, it will never have enought strength to put an end to capitalism.

Therefore, if there is nothing, from an economical point of view, that postulates the disappearance of capitalim, the sociological and psychological reasons expouded by Schumpeter have the same weakness of ideological statements.

Jean-Jacques Salomon é diretor do Centro de Ciência, Tecnologia e Sociedade do Conservatoire National des Arts e Métiers de Paris. Fez a Conferência do Mês de outubro de 1991 do IEA sobre "Políticas Públicas, Tecnologia e Desenvolvimento".

Este texto é um capítulo do livro Les ruses de la raison - technologie, capitalisme, dénocratie, a ser proximamente publicado em Paris.

Tradução de Belkiss Jasinevicius Rabello. Revisão de Alfredo Bosi. O original em francês encontra-se à disposiçăo do leitor no IEA para eventual consulta. 